\title{
CHANGES IN THE FDI POLICY WITH SPECIAL REFERENCE TO E-COMMERCE IN INDIAN RETAIL SECTOR AND IT'S COMPLIANCE STRATEGIES AS ADOPTED BY FLIPKART AND AMAZON: AN OBSERVATIONAL REVIEW
}

\author{
Dr. Heena Vaidya, Dr. Ijan Vaidya \\ Assistant Professor- Accountancy \& Commerce, Dolat-Usha Institute of Applied Sciences and Dhiru-Sarla \\ Institute of Management and Commerce, Valsad \\ Email-vadesaheena@gmail.com
}

Assistant Professor- Commerce, Government Arts and Commerce College Bhilad Email- ijanvaidya@gmail.com

\begin{abstract}
The paper tries to analytically observe the chronological changes as incurred in the Foreign Direct Investment (FDI) policy with special reference to e-commerce in Indian retail sector. Across the last two decades, there have been plentiful changes in such e-commerce related FDI policy as the whole sector itself was fresh and just evolving in our country. The policy makers have time to time grew with the complex tactics and inscrutable business strategies used by giant e-commerce companies like Flipkart and Amazon in India. Over the years from their entry in India till date, these companies have been burning cash through deep-discounts, unfair marketing experiments through exclusive deals/offers and what not, just to gain a huge slice in the market-share race. These companies have developed complex business structures just to 'comply' with the rules of Indian government's policies on FDI. The policy makers on the other hand have not let it loose and have regularly tightened the noose with astute comebacks, through regular changes in the FDI policy. The paper thus, tries to conclude through critically reviewing the compliance strategies as implemented by both e-tail giants in India and how they changed the game when the government changed rules of the game.
\end{abstract}

Key words - Foreign Direct Investment, E-commerce, Marketplace Model, Flipkart and Amazon

\section{INTRODUCTION}

Ever-since the concept of E-commerce evolved in India, the government is trying its best to keep it self equally updated through amending the rules and regulations drastically and frequently. The super lucrative ecommerce business in India has opened up an entirely new avenue/window for Foreign Investors as well as Indian start-ups. The world that we are living in today has around 3.5 billion smart-phone users, and with almost $30 \%$ of them being Indian users, the potential of e-commerce sector in India is beyond imagination. At present e-commerce sales in India is only $2.2 \%$ of the total retail sales in the country. It has immense growth potential of around $24 \%$ per annum and active e-commerce penetration of around $74 \%$.

With all these impressive data around, foreign players like Amazon and Walmart are the two giants that are fighting for the maximum share of this golden bread. The international investor pressure has led the government to relax the FDI norms to certain extent, even though such policies has continuously faced protest and opposition from the widespread non-electronic Indian Retail market.

\section{OBSERVATIONS OF MAJOR CHANGES IN THE TRADING RELATED FDI POLICY WITH SPECIAL REFERENCE TO E-COMMERCE THROUGH A TIME-LINE (TABLE-1)}

\begin{tabular}{|l|l|l|}
\hline Chronology & Amendment/Clarification/Notification & Review of the Rule \\
\hline 11/02/2000 & Trading & There was no mention of "E-commerce" \\
Press Note 2 & $\begin{array}{l}\text { Trading is permitted under automatic route with FDI up to 51\% } \\
\text { provided it is primarily export activities, and the undertaking is an } \\
\text { export house/trading house/super trading house/star trading } \\
\text { trase. However, under the Foreign Investment Promotion Board } \\
\text { house the Policy up till Feb. } \\
\text { route: - } \\
\begin{array}{l}\text { 1) } \mathbf{1 0 0 \%} \text { FDI IS PERMITTED in case of trading companies for } \\
\text { the following activities: }\end{array}\end{array}$ \\
\hline
\end{tabular}




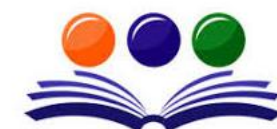

GRAND ACADEMIC PORTAL RESEARCH JOURNALS

\begin{tabular}{|c|c|c|}
\hline & $\begin{array}{l}\text { a) exports; } \\
\text { b) bulk imports with export/exbonded warehouse sales; } \\
\text { c) cash and carry wholesale trading; } \\
\text { d) other import of goods or services provided at least } 75 \% \text { is for } \\
\text { procurement and sale of goods and services among the companies } \\
\text { of the same group and for third party use or onward } \\
\text { transfer/distribution/sales. } \\
\text { 2) The following kinds of trading are also PERMITTED, subject to } \\
\text { provisions of EXIM Policy: } \\
\text { a. Companies for providing after sales services (that is no trading } \\
\text { per se) } \\
\text { b. Domestic trading of products of JVs is permitted at the } \\
\text { wholesale level for such trading companies who wish to market } \\
\text { manufactured products on behalf of their joint ventures in which } \\
\text { they have equity participation in India. } \\
\text { c. Trading of hi-tech items/items requiring specialized after sales } \\
\text { service } \\
\text { d. Trading of items for social sector } \\
\text { e. Trading of hi-tech, medical and diagnostic items. } \\
\text { f. Trading of items sourced from the small-scale sector under } \\
\text { which, based on technology provided and laid down quality } \\
\text { specifications, a company can market that item under its brand } \\
\text { name. } \\
\text { g. Domestic sourcing of products for exports. } \\
\text { h. Test marketing of such items for which a company has } \\
\text { approval for manufacture provided such test marketing facility } \\
\text { will be for a period of two years, and investment in setting up } \\
\text { manufacturing facilities commences simultaneously with test } \\
\text { marketing. }\end{array}$ & \\
\hline $\begin{array}{l}14 / 7 / 2000 \\
\text { Press Note } 7\end{array}$ & $\begin{array}{l}\text { Foreign Direct Investment up to } 100 \% \text { is allowed for e-commerce } \\
\text { activities subject to the condition that such companies would } \\
\text { divest } 26 \% \text { of their equity in favor of the Indian public in } 5 \text { years, } \\
\text { if these companies are listed in other parts of the world. } \\
\text { Further, these companies would engage only in business to } \\
\text { business (B2B) ecommerce and Not in retail trading, inter alia, } \\
\text { implying that existing restrictions on FDI in domestic trading } \\
\text { would be applicable to e-commerce as well. }\end{array}$ & $\begin{array}{l}\text { For the first time, E-commerce Activities } \\
\text { through FDI was permitted through this } \\
\text { circular of July, } 2000 \text {. Though only in B2B } \\
\text { and that too with certain conditions, this } \\
\text { was a landmark update in the context of E- } \\
\text { commerce trading activities. } \\
\text { (A another Press note (No.8) which was } \\
\text { issued in August 2000, clearly mentioned } \\
\text { that B2C is NOT Permitted in E-commerce } \\
\text { Activities and that it should be clearly } \\
\text { excluded while considering the FDI with } \\
\text { reference to E-commerce in India) }\end{array}$ \\
\hline \multicolumn{3}{|c|}{$\begin{array}{l}\text { *Surprisingly there was no written communication from the government with regards to e-commerce in India during } 2000-2006 . \text { May } \\
\text { be the industry and government were both in the 'Shall Take Our Own Time' phase. There weren't many players in the industry and the } \\
\text { market was still living in the 'Yuga' before the disruptive e-revolution shook entire premise of commerce and related activities. But } \\
\text { what is more revealing that even as far as FDI in 'Retail Trading' is concerned, there were no updates from government's quiver. }\end{array}$} \\
\hline $\begin{array}{l}10 / 2 / 2006 \\
\text { Press Note } 3\end{array}$ & $\begin{array}{l}\text { FDI up to } 51 \% \text { in retail trade of 'Single Brand' products was } \\
\text { allowed subject to prior permission from government and some } \\
\text { conditions like: } \\
\text { i. Products to be sold should be of a 'Single Brand' only. } \\
\text { ii. Products should be sold under the same brand internationally. } \\
\text { iii. 'Single Brand' product-retailing would cover only products } \\
\text { which are branded during manufacturing. }\end{array}$ & $\begin{array}{l}\text { This classic decision became a benchmark } \\
\text { open gate for all the foreign retailers eyeing } \\
\text { billions of dollars' worth Indian retail } \\
\text { segment, which was highly dominated then } \\
\text { by lacs of small scale brick and mortar } \\
\text { outlets across India involved in various sorts } \\
\text { of retailing. }\end{array}$ \\
\hline $\begin{array}{l}16 / 6 / 2008 \\
\text { Press Note } 7\end{array}$ & 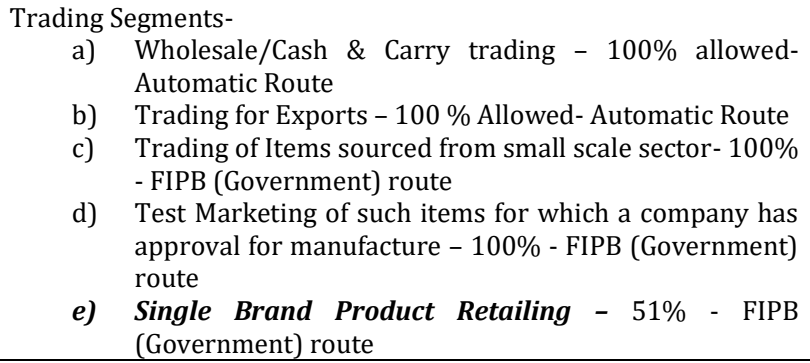 & $\begin{array}{l}\text { Via this press note, the government clarified } \\
\text { the sub-segments in Retail Trading and also } \\
\text { gave acute information regarding the route } \\
\text { to be followed while bringing in the FDI in } \\
\text { Retail sector. It stayed put to its earlier point } \\
\text { with reference to single brand product } \\
\text { retailing. Also there is no clarification in } \\
\text { context of E-commerce activities in Trading } \\
\text { beyond the year } 2000 \text { circular. }\end{array}$ \\
\hline $\begin{array}{l}\text { FDI Policy, } \\
2010\end{array}$ & $\begin{array}{l}\text { The regulations and conditions as amended uptill } 2008 \text { remains } \\
\text { the same. }\end{array}$ & $\begin{array}{l}\text { No changes in the policy further with } \\
\text { reference to Retail trading. }\end{array}$ \\
\hline $\begin{array}{l}2012 \\
\text { Press Note } 1 \\
10 / 1 / 2012\end{array}$ & $\begin{array}{l}\text { The 51\% restriction with reference to Single Brand Retail Trading } \\
\text { was lifted and } 100 \% \text { FDI was welcomed in this segment of } \\
\text { Trading. Also, the route still remained government, but definition } \\
\text { of Single brand was elaborated alongwith the conditions to be } \\
\text { fulfilled while allowing such FDI with open arms- } \\
\text { (a) Products to be sold should be of a 'Single Brand' only. } \\
\text { (b) Products should be sold under the same brand internationally }\end{array}$ & $\begin{array}{l}\text { Foreign Investment in Single Brand product } \\
\text { retail trading was targeted at attracting } \\
\text { investments in production and marketing, } \\
\text { improving the availability of such goods for } \\
\text { the consumer, encouraging increased } \\
\text { sourcing of goods from India, and enhancing } \\
\text { competitiveness of Indian enterprises }\end{array}$ \\
\hline
\end{tabular}




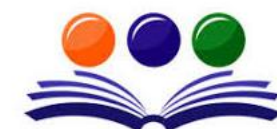

GRAND ACADEMIC PORTAL RESEARCH JOURNALS

\begin{tabular}{|c|c|c|}
\hline & $\begin{array}{l}\text { i.e. products should be sold under the same brand in one or more } \\
\text { countries other than India. } \\
\text { (c) 'Single Brand' product-retail trading would cover only } \\
\text { products which are branded during manufacturing. } \\
\text { (d) The foreign investor should be the owner of the brand. } \\
\text { (e) In respect of proposals involving FDI beyond } 51 \% \text {, mandatory } \\
\text { sourcing of at least } 30 \% \text { of the value of products sold would have } \\
\text { to be done from Indian 'small industries/ village and cottage } \\
\text { industries, artisans and craftsmen'. 'Small industries' would be } \\
\text { defined as industries which have a total investment in plant \& } \\
\text { machinery not exceeding US } \$ 1.00 \text { million. This valuation refers } \\
\text { to the value at the time of installation, without providing for } \\
\text { depreciation. } \\
\text { Further, if at any point in time, this valuation is exceeded, the } \\
\text { industry shall not qualify as a 'small industry' for this purpose. } \\
\text { The compliance of this condition will be ensured through self- } \\
\text { certification by the company, to be subsequently checked, by } \\
\text { statutory auditors, from the duly certified accounts, which the } \\
\text { company will be required to maintain. }\end{array}$ & $\begin{array}{l}\text { through access to global designs, } \\
\text { technologies and management practices. } \\
\text { The amendments in the Single Brand } \\
\text { retailing were apt and it laid a clear vision of } \\
\text { the Indian government with reference to its } \\
\text { allowance of FDI as well as protecting its } \\
\text { long standing local retail industry. This is an } \\
\text { iconic amendment that justifies how justice } \\
\text { can be served while keeping both ends } \\
\text { happy. }\end{array}$ \\
\hline $\begin{array}{l}2012 \\
\text { Press Note } 4 \\
20 / 9 / 2012\end{array}$ & $\begin{array}{l}\text { The clauses which are mentioned as conditions to Single Brand } \\
\text { Retail trading in the above press note where further amended and } \\
\text { the clauses d, e,f where inserted as below- } \\
\text { (d) Only one non-resident entity, whether owner of the brand or } \\
\text { otherwise, shall be permitted to undertake single brand product } \\
\text { retail trading in the country, for the specific brand, through a } \\
\text { legally tenable agreement, with the brand owner for undertaking } \\
\text { single brand product retail trading in respect of the specific brand } \\
\text { for which approval is being sought. The onus for ensuring } \\
\text { compliance with this condition shall rest with the Indian entity } \\
\text { carrying out single-brand product retail trading in India. The } \\
\text { investing entity shall provide evidence to this effect at the time of } \\
\text { seeking approval, including a copy of the licensing, franchise/sub- } \\
\text { licence agreement, specifically indicating compliance with the } \\
\text { above condition. } \\
\text { (e) In respect of proposals involving FDI beyond 51\%, sourcing of } \\
30 \% \text { of the value of goods purchased, will be done from India, } \\
\text { preferably from MSMEs, village and cottage industries, artisans } \\
\text { and craftsmen, in all sectors. The quantum of domestic } \\
\text { sourcing will be self-certified by the company, to be subsequently } \\
\text { checked, by statutory auditors, from the duly certified accounts } \\
\text { which the company will be required to maintain. This } \\
\text { procurement requirement would have to be met, in the first } \\
\text { instance, as an average of five years' total value of the goods } \\
\text { purchased, beginning lst April of the year during which the first } \\
\text { tranche of FDI is received. } \\
\text { Thereafter, it would have to be met on an annual basis. For the } \\
\text { purpose of ascertaining the sourcing requirement, the relevant } \\
\text { entity would be the company, incorporated in India, which is the } \\
\text { recipient of FDI for the purpose of carrying out single-brand } \\
\text { product retail trading. } \\
\text { (f) Retail trading, in any form, by means of e-commerce, would } \\
\text { not be permissible, for companies with FDI, engaged in the } \\
\text { activity of single-brand retail trading. }\end{array}$ & $\begin{array}{l}\text { This pressnote was released with special } \\
\text { reference to banning several e-commerce } \\
\text { entitities operating in India but having } \\
\text { financial traces leading in foreign countries. } \\
\text { The clause 'f laid down as a condition for } \\
\text { single brand retail trading speciafically } \\
\text { mentions about disallowance of e-commerce } \\
\text { actitivities. } \\
\text { This came as a huge blow to the e-commerce } \\
\text { platforms operating in India under fake } \\
\text { shield of being Indian company. }\end{array}$ \\
\hline $\begin{array}{l}20 / 9 / 2012 \\
\text { Press Note } 5\end{array}$ & $\begin{array}{l}\text { Press Note 5- FDI was prohibited in retail trading, except in Single } \\
\text { Brand retail trading (in which } 100 \% \text { was permitted under Govt } \\
\text { route) } \\
\text { Hence, with this Press Note, Government permitted upto 51\% FDI } \\
\text { for Multi Brand Retail Trading subject to certain conditions.- } \\
\text { 1) Fresh agricultural produce, including fruits, vegetables, flowers, } \\
\text { grains, pulses, fresh poultry, fishery and meat products, may be } \\
\text { unbranded. } \\
\text { 2) Minimum amount to be brought in, as FDI, by the foreign } \\
\text { investor, would be US } \$ 100 \text { million. } \\
\text { 3) At least } 50 \% \text { of total FDI brought in shall be invested in } \\
\text { 'backend infrastructure' within three years of the first tranche of } \\
\text { FDI, where 'back-end infrastructure' will include capital } \\
\text { expenditure on all activities, excluding that on front-end units; for } \\
\text { instance, back-end infrastructure will include investment made } \\
\text { towards processing, manufacturing, distribution, design } \\
\text { improvement, quality control, packaging, logistics, storage, ware- } \\
\text { house, agriculture market produce infrastructure etc. Expenditure } \\
\text { on land cost and rentals, if any, will not be counted for purposes of } \\
\text { back end infrastructure. }\end{array}$ & $\begin{array}{l}\text { The word 'Multi Brand Retail Trading' was } \\
\text { introduced and addressed for the first time } \\
\text { in the context of FDI policy. Before this press } \\
\text { note, there was no clarity of regarding this } \\
\text { which was till then seen as a lacuna by many } \\
\text { e-commerce platforms operating freely in } \\
\text { India. Company like Flipkart had it's offices } \\
\text { registered outside of India and hence, } \\
\text { Flipkart directly couldn't sell anything in } \\
\text { India under the same banner. However, in } \\
\text { the rule book the rule was regarding direct } \\
\text { selling of goods by the company to the } \\
\text { consumers. So these companies argued that } \\
\text { they were just platform providers but by } \\
\text { that time such companies had already found } \\
\text { out different way and continued selling } \\
\text { things through various seller companies } \\
\text { being directly or indirectly owned by the } \\
\text { owners or having some linkages with the } \\
\text { founders of Flipkart. One such major seller } \\
\text { was WS Retail on Flipkart and the detailed }\end{array}$ \\
\hline
\end{tabular}




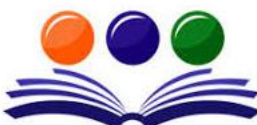

GRAND ACADEMIC PORTAL RESEARCH JOURNALS

\begin{tabular}{|c|c|c|}
\hline & 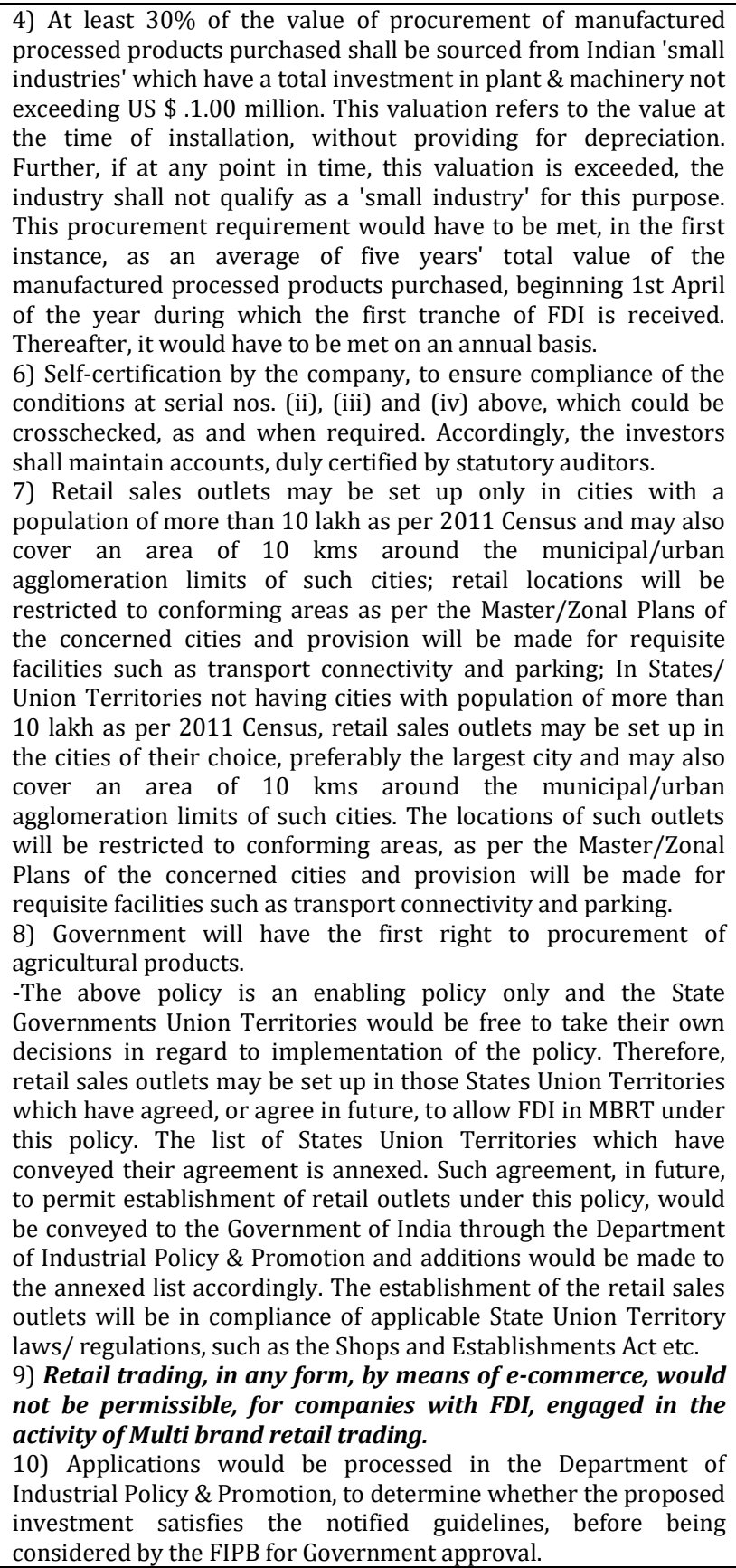 & $\begin{array}{l}\text { story of the same is discussed later in this } \\
\text { paper. } \\
\text { The government via one of the conditions in } \\
\text { this press note for FDI in the 'Multi Brand } \\
\text { Retail Trading' made it crystal clear that in } \\
\text { no ways it would entertain any B2C ' e- } \\
\text { commerce' in Single or Multi Brand. But } \\
\text { because still there was no clear cut rules for } \\
\text { e-commerce platform providers, they } \\
\text { enjoyed their billions of dollars flowing in } \\
\text { and out of their companies without any } \\
\text { grief. }\end{array}$ \\
\hline $\begin{array}{l}22 / 8 / 2013 \\
\text { Press Note } 5\end{array}$ & $\begin{array}{l}\text { With reference to the new segment of Multi Brand Retailing } \\
\text { opened by the government, certain conditions as mentioned above } \\
\text { were revised. } \\
\text { The summary of revision is as follows- } \\
\text { - There was no mention of an amount to be brought in } \\
\text { the first tranche of capital and to be invested in the } \\
\text { backend activities. With this the government specified } \\
\text { at least } \$ 100 \text { mn to be brought in } \\
\text { With reference to the condition stating mandatory } \\
\text { buying of at least } 30 \% \text { from a small scale industries, the } \\
\text { definition of small industries was altered with this } \\
\text { amendment. Now, any industry having total plant and } \\
\text { machinery investment not exceeding } \$ 2 \text { mn (which was } \\
\text { earlier } \$ 1 \text { mn) shall be considered small scale. Not only } \\
\text { that, it was stated earlier that the status of 'Small Scale } \\
\text { Industry' shall be snatched if on any given day such } \\
\text { investment exceeded the limit. Such a clause was done } \\
\text { away with via this press note and clarification was } \\
\text { given that the formalities to allow such status shall be } \\
\text { reckoned only once at the beginning of the process. } \\
\text { The clause of selecting the location for the multi brand }\end{array}$ & $\begin{array}{l}\text { One of the amendments in this press note } \\
\text { came as a major relief for the small scale } \\
\text { industries as compared to the earlier one. } \\
\text { The earlier clause of snatching away the } \\
\text { status of small scale industry if the plant and } \\
\text { machinery investment exceeded the limit } \\
\text { was simply creating tension amidst the } \\
\text { small and medium enterprise lobby. Such a } \\
\text { clause was absolutely done away with, the } \\
\text { limit was raised from } \$ 1 \text { mn to } \$ 2 \text { mn and the } \\
\text { formality was to be complied with only once. } \\
\text { Even the amendment with reference to } \\
\text { selection of place for setting up an outlet } \\
\text { was liberated from extreme restrictions and } \\
\text { only major consideration now was } \\
\text { population exceeding } 10 \text { lacs. This also was } \\
\text { bit of a relief for the foreign investors who } \\
\text { would otherwise be burdened with } \\
\text { fulfillment of unnecessary formalities. This } \\
\text { does count as an amendment to ensure 'ease } \\
\text { of doing business'. }\end{array}$ \\
\hline
\end{tabular}




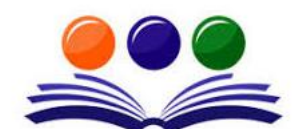

GRAND ACADEMIC PORTAL RESEARCH JOURNALS

\section{A GLOBAL JOURNAL OF SOCIAL SCIENCES}

( ISSN - 2581-5830 )

Impact Factor: SJIF - 4.998, IIFS - 4.375

\begin{tabular}{|c|c|c|}
\hline & $\begin{array}{l}\text { retail outlet was much restrictive in nature, which was } \\
\text { amended and much of the decisions regarding where to } \\
\text { establish such outlet were left upon the state } \\
\text { governments and local administrations. The only major } \\
\text { criterion that was supposed to be considered while } \\
\text { selecting location was population beyond } 10 \text { lacs. }\end{array}$ & \\
\hline $\begin{array}{l}2013 \\
\text { Press Note } 6\end{array}$ & $\begin{array}{l}\text { The summary of the amendment is as follows- } \\
\text { - } \quad \text { The policy was eased with reference to FDI in Single } \\
\text { Brand Retail trading and for and entity having less than } \\
\text { 49\% share could now operate on the automatic route } \\
\text { (i.e. Government permission required only beyond } \\
\text { 49\%) } \\
\text { Also for Single Brand Retail, requisite copy of its } \\
\text { approval and other agreements signed with the Indian } \\
\text { entity shall have also to be filed with RBI }\end{array}$ & $\begin{array}{l}\text { The amendment was seen a booster for FDI } \\
\text { in Single Brand retailing since now foreign } \\
\text { entities engaged in such activities in India } \\
\text { having less than } 49 \% \text { share could easily } \\
\text { operate without falling prey to redundant } \\
\text { and time consuming bureaucratic } \\
\text { formalities. }\end{array}$ \\
\hline $\begin{array}{l}12 / 5 / 2015 \\
\text { Press Note } \\
12\end{array}$ & $\begin{array}{l}\text { Any Single Brand Retail trading entity having Brick and Mortar } \\
\text { outlets was permitted to operate through 'e-commerce' }\end{array}$ & $\begin{array}{l}\text { The amendment to allow brick and mortar } \\
\text { Single Brand retail trading entities to do e- } \\
\text { commerce activities was welcomed by many } \\
\text { such foreign giants already operating in } \\
\text { India }\end{array}$ \\
\hline $\begin{array}{l}29 / 3 / 2016 \\
\text { Press Note } 3\end{array}$ & $\begin{array}{l}\text { B2C e-commerce which wasn't allowed till date was now } \\
\text { allowed subject to following circumstances- } \\
\text { - A manufacturer is permitted to sell his products } \\
\text { manufactured in India via e-commerce } \\
\text { A single brand retail trading entity already owning } \\
\text { brick and mortar stores is permitted for e-commerce } \\
\text { - An Indian manufacturer is permitted to sell its own } \\
\text { single brand products through e-commerce. } \\
\text { The government made it clear that it was not yet ready for the } \\
\text { inventory based model } \\
\text { Other major conditions laid were as follows- } \\
\text { - Marketplace entities will be allowed to enter into } \\
\text { transactions with sellers registered on its platform on } \\
\text { B2B basis } \\
\text { E-commerce entity will not exercise any ownership } \\
\text { over inventory } \\
\text { An e-commerce entity will not permit more than } 25 \% \\
\text { of the sales affected through its marketplace from one } \\
\text { vendor or their group companies } \\
\text { Payments of sale may be facilitated by the e-commerce } \\
\text { entity in accordance with guidelines of RBI and that any } \\
\text { warranty/guarantee shall be responsibility of the seller } \\
\text { and not e-commerce entity } \\
\text { E-commerce entity will not directly or indirectly } \\
\text { influence the sale price of goods or services and shall } \\
\text { maintain level playing field. }\end{array}$ & $\begin{array}{l}\text { This circular became a benchmark } \\
\text { announcement opening up considerable } \\
\text { gates for e-commerce retail trading activity } \\
\text { in India for foreign players. One of the most } \\
\text { crucial policy decision being undertaken by } \\
\text { the new government formed in } 2014 \text { was to } \\
\text { officially allow the marketplace model of e- } \\
\text { commerce are far as retail trading is } \\
\text { concerned. } \\
\text { Also the government defined E-commerce, } \\
\text { E-commerce entity, Inventory based model } \\
\text { and Market place based model. } \\
\text { The government allowed only marketplace } \\
\text { model and disallowed inventory based } \\
\text { model, which would result into a confusion } \\
\text { for many e-commerce giants in India since } \\
\text { they were also selling their own products on } \\
\text { their 'marketplace' based platform. Now } \\
\text { they couldn't keep inventory in their own } \\
\text { name. }\end{array}$ \\
\hline $\begin{array}{l}2016 \\
\text { Press Note } 5\end{array}$ & No major change impacting the e-commerce trading & - $\quad$ No major change \\
\hline $\begin{array}{l}2018 \\
\text { Press Note } 1\end{array}$ & $\begin{array}{l}\text { Single Brand Retail Trading again go back to fully automatic route } \\
\text { (government route beyond } 49 \% \text { done away with) }\end{array}$ & No major change \\
\hline $\begin{array}{l}26 / 12 / 2018 \\
\text { Press Note } 2\end{array}$ & $\begin{array}{l}\text { The press note made it pretty clear that E-commerce entities in } \\
\text { India shall be allowed only B2B and not B2C. } \\
\text { 100\% FDI under automatic route is permitted in Marketplace } \\
\text { model only. (Inventory based model of e-commerce not allowed) } \\
\text { Major conditions (as amended) } \\
\text { - Marketplace E-commerce entity will NOT EXERCISE any } \\
\text { ownership or any control on the goods or services } \\
\text { intended to be sold. If in any case it does so, it shall be } \\
\text { treated as inventory based model (which for time being }\end{array}$ & $\begin{array}{l}\text { After the } 2016 \text { official allowance by the } \\
\text { government to the e-commerce entities via } \\
\text { marketplace platform subject to certain } \\
\text { conditions, the existing players of the } \\
\text { industry found loopholes in the system and } \\
\text { continued their dream run of selling goods } \\
\text { and services worth billions of dollars in } \\
\text { India through their own group companies or } \\
\text { other indirect ownerships. }\end{array}$ \\
\hline
\end{tabular}




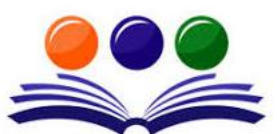

GRAND ACADEMIC PORTAL RESEARCH JOURNALS
A GLOBAL JOURNAL OF SOCIAL SCIENCES

( ISSN - 2581-5830 )

Impact Factor: SJIF - 4.998, IIFS - 4.375

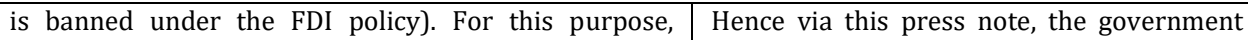
inventory of a vendor shall be treated to be controlled by e-commerce platform provider if such a vendor purchases more than $25 \%$ from the e-commerce platform provider or it's group companies.

Any entity having equity participation or any control on its inventory by e-commerce marketplace entity or it's group companies of such platform provider, will NOT BE PERMITTED to sell its goods on such platform run by market place entity

The services provided by the platform to it's vendors shall be fair and non-discriminatory for all the vendors. The vendors having traces (either via equity participation or inventory control) with the ecommerce platform provider directly or through it's group companies shall not provide any unfair or discriminatory CASHBACKs. There should not be any undue influence on selling price that don't maintain level playing field.

- $\quad$ E-commerce platform provider will NOT MANDATE any seller to sell any product exclusively on its platform only. down heavily on the e-commerce platform providers by making it clear as water that by "marketplace" the government means "marketplace" and not "inventory" based. Any sort of malicious or scrupulous relationship or linkages found between the vendors on the platform and the platform provider will be unacceptable by all means. As a result e-commerce giants had to make major changes in their existing corporate structure. The details of the same are later discussed in the chapter.

Every single problem creating an unfair advantage to the online platforms was addressed in this press note. The government laid out flawless guidelines considering the benefit of mammoth-some organized and unorganized brick and mortar Indian retail market. This circular may have upset the tech-savvy and frequently online buying community of consumers, as it was made plain by the government that in future, the deep discounts and extra cashbacks; one of the major factors appealing the folks to buy online than offline, will no more be found on the online platforms.

The exclusivity of the deals (often seen on electronic items like mobile-phones sold on e-commerce platforms) was asked to be ceased by the government. From the early cases it was evident that often these platforms in order to cut competition and provide exclusivity, made agreements with the manufacturers to sell on their individual platform ONLY. For example, companies like Xiaomi sold much of their phones earlier exclusively on a particular e-platform via flash sale. Such phones weren't available in the offline retail market nor on the competitor's e-platform because of the signed agreement of exclusivity between the manufacturer and the e-platform.

Amazon and Flipkart, both giants were taken aback by such move from the government and had to halt their platform for a while to restructure their strategy, which is discussed in detail later in the chapter. 


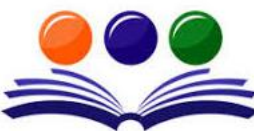

GRAND ACADEMIC PORTAL RESEARCH JOURNALS

\section{Companies owned by Flipkart Private Limited (Singapore)}

The above company was incorporated on Oct 4th, 2011 which remained the ultimate holding company of the web of comapnies

\section{SHARE OF FLIPKART PRIVATE LIMITED}

Flipkart India Pvt. Ltd. Incorporated in Sep. 2011 (It became the main Indian arm for Cash and Carry Wholesale entity). It was born by purchasing the original company of flipkart group- Flipkart Online Services Pvt. Itd. Which was incorporated in Oct. 2008
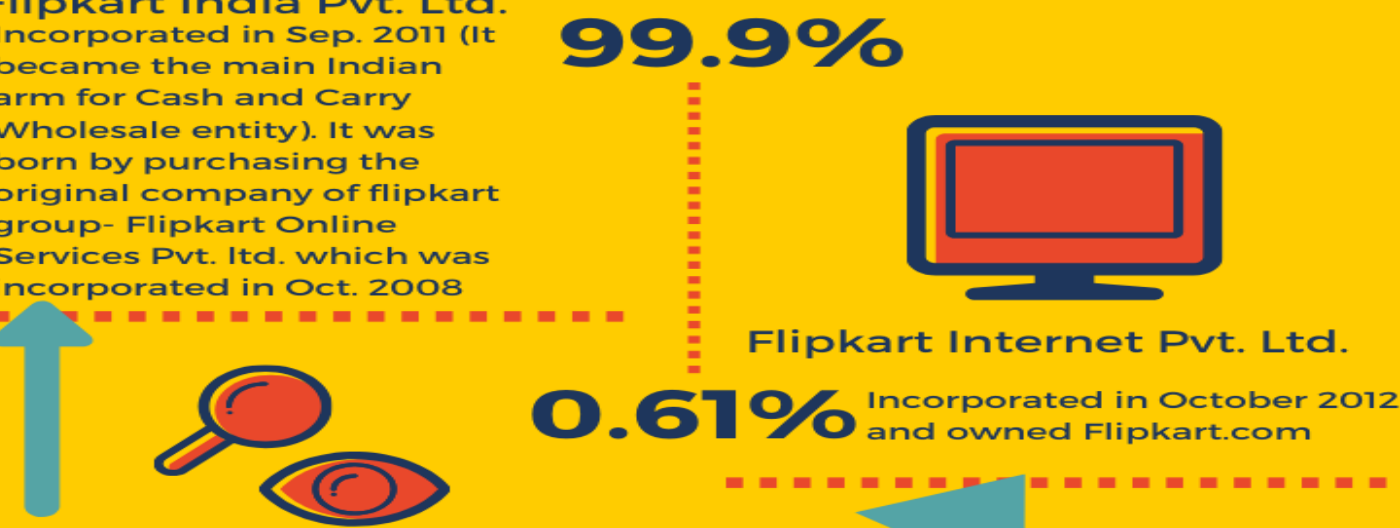

Flipkart Marketplace Pvt. Ltd (Singapore). Incorporated in September 2012 and owned $99.39 \%$ share in Flipkart Internet Private Limited. It also owned $0.1 \%$ share in Flipkart India Pvt. Ltd.

Flipkart Payment Gateway This was previously known as
Flipkart Digital Private Limited. Incorporated in December 2011
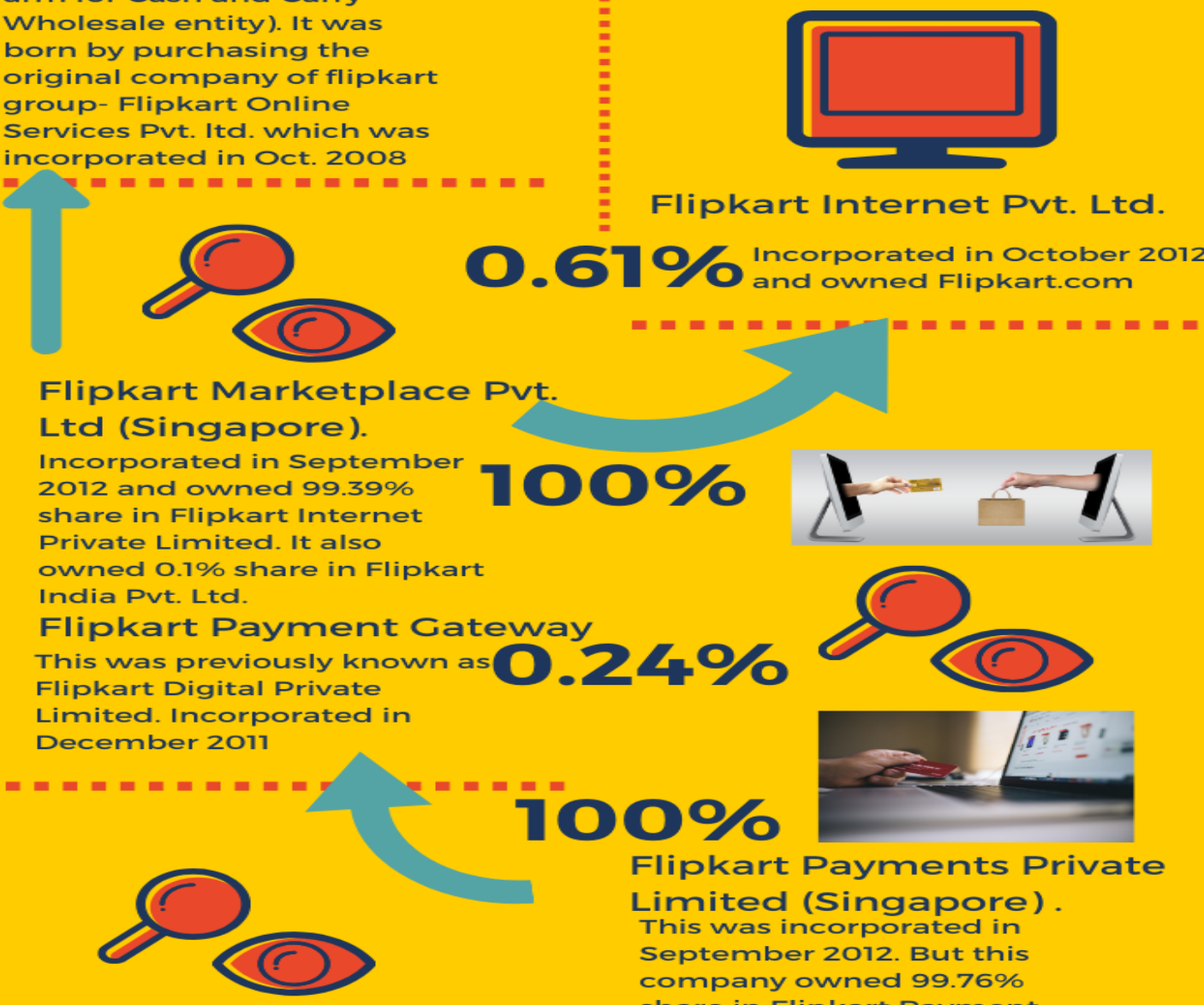

Flipkart Payments Private Limited (Singapore). This was incorporated in September 2012. But this company owned $99.76 \%$ share in Flipkart Payment Gateway Private Limited

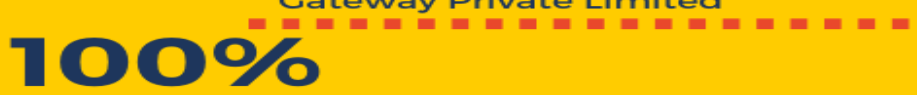

Flipkart Digital Media Private Limited . This was Incorporated in November 2010

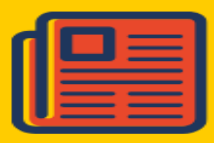

Flipkart Logistics Private Limited (Singapore) This was Incorporated in September 2012

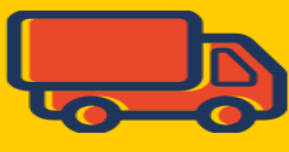

In short, the company in Singapore i.e. Flipkart Private Limited controlled directly or indirectly every other companies in this complex web structure. 


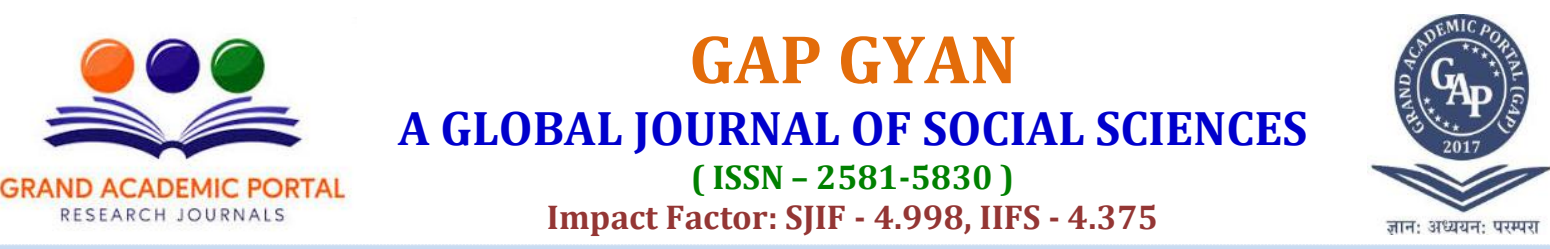

3. FLIPKART'S CONTINUOUS RESPONSE TO THE CHANGES IN FDI NORMS: A REVIEW

Flipkart in the past has been in the suspicious scanner by various bodies of government, especially with Enforcement Directorate probing into the matters of Flipkart as well as Myntra (it's group company) for alleged FEMA violations and not following the FDI policy of India. However, later by 2017 the Enforcement Directorate had given Flipkart a complete clean cheat and any rumors of government laying heavy penalty on our own Indian e-commerce giant were done away with. This definitely came as a happy news for Flipkart, but its financial numbers in the balance sheet still doesn't give positive signals, which again is a matter of another research article.

The name of the original company was Flipkart Online Sevices Private Limited, which sold it's entire business to Flipkart India Private Limited in December 2011 held by Sachin and Binny Bansal, Tiger Global and Accel Partners back then. The Bansals created a web of companies, for reasons only they might be able to explain meticulously. The picture as given here explains well how these web of companies operated.

This picture represents the scene around 2013 when the law makers realized for the first time that something like e-commerce (with special reference to B2C) has already entered the doors of India and policies need to be framed to regulate the same.

However, Flipkart's drama can be divided into three parts. Part 1 shall be from 2008 to 2012 (when for the first time a FDI policy was dropped as a bomb with special reference to ceasing of inventory based model), Part 2 from 2012 to May 2018 (when Walmart acquired it in May '18) and Part 3 (story continues with high voltage drama of restructuring and re-strategizing the company after there came major changes in FDI policy in December 2018)

\subsection{Flipkart - Part 1 (2008-12)}

Flipkart started its operations in India around October 2008. But the story of FDI in retail started in 2006 when the government loosened regulations on FDI in wholesale (B2B) and single brand retail. However, the government was still silent on Multi brand Retail Trading and it was hence considered to be close. Flipkart took outright advantage of this loophole and began in 2008 it's operations. Though prima facie it looked like a retailer to the buyers on the platform, it actually 'ON PAPER' was a wholesaler which was allowed or say, the government was silent in context of e-commerce. The Bansals besides setting up Flipkart, also set up an Indian company called WS Retail specially for the purpose of selling goods to the customers on the platform. On any given day prima-facie, it always looked that Flipkart was just a "marketplace/platform" and not a direct seller. However, WS Retail for years was the main vendor on their platform and for years it occupied gigantic share in sales on their platform. But a major bomb was dropped by then industry minister Anand Kumar in the form of amendment in the rules of FDI via Press note 4 and 5 released by September 2012. For the first time the government defined Multi Brand Retail trading, formed rules to allow it and also banned any sort of "B2C". The Bansals hence thought it wise enough to exit from the WS Retail (which was being based at a 'small sleepy house' in Bangalore and anyone inquiring more about the address of WS Retail in detail was directed towards the headquarters of Flipkart that was few kilometers away(The Caravan, 2014))

3.2. Flipkart - Part 2 : The drama of Cash burn, Competition and WS Retail dream run (2012-2018) But did they really exit WS retail? Well, in February 2013 WS retail was sold out to a group of High Networth Individual Investors led by OnMobile COO Rajiv Kuchhal, and few important employees of Flipkart. By April 2013, Flipkart had embraced 'Marketplace' model at bird's eye view. But even after officialy parting from WS Retail, it remained to be major vendor on Flipkart and used to process almost half of Flipkart's revenue. Such dream run of WS Retail continued till financial year 2016 by which its turnover was around 13921 crores from around 3000 crore in 2014. During these years it had formed many "exclusive" partnerships with Motorola and Xiaomi to sell their mobile phones. This was the era of smart-phone revolution in India with number of Indian and Chinese companies bringing in numerous cheap models priced at almost $1 / 5^{\text {th }}$ as compared to the prices of Flagship phones from international brands like Apple and Samsung. Such exclusive partnerships covered that such companies won't sell such phones either in offline market or even on the competitor's website. The features of the phone are so alluring and at an unbelievable price that 'otherwise brick and mortar friendly' consumers literally didn't mind bit buying it online. The consumers benefitted a lot in the beginning because of cashbacks and deep-discounts being offered by Flipkart and Amazon in classic cut-throat competition. Meanwhile, Flipkart had added Myntra in 2014 for $\$ 300 \mathrm{mn}$ and Jabong in 2016 for \$70mn to its bucket of companies giving itself an added advantage over Amazon in terms of apparel, footwear and accessories buying. The competition between the two was so tough that in search of 'Market Share' both companies ended up burning enormous amount of cash even for the 'marketplace' model.

But as they say 'just when everything seems to be normal' and problems seem to have ended, don't be relaxed for it might be signs of a Tsunami coming ahead. In March 2016, Government dropped another bomb by adding a clause to the FDI policy for Retail trading. The government now officially allowed the e-commerce in India via 'marketplace' model through it's Press note no. 3 published in March 2016. One of the clause in this press note barred any particular vendor to sell on a particular marketplace where he is contributing more than $25 \%$ of the 


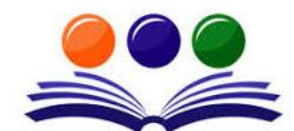

GRAND ACADEMIC PORTAL RESEARCH JOURNALS

\section{A GLOBAL JOURNAL OF SOCIAL SCIENCES}

( ISSN - 2581-5830 )

Impact Factor: SJIF - 4.998, IIFS - 4.375

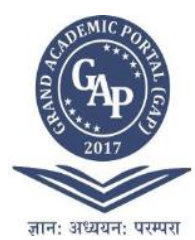

total sales on that platform. WS Retail was contributing around half of the revenue on Flipkart. So again, Flipkart had to do something. It came up with unique solution to this. It floated new companies and also entered into agreements with HNI's already existing companies into wholesale trading in India (eg. Retail Net Pvt. Ltd.) with single aim to offload the share of sales of WS Retail alone. This although came as a sad news for WS Retail, since it's revenue witnessed 66\% percent wash-off and the revenues of the FY 2017 were reduced to around 4628.1 crore. (Entrackr.com). By 2018, Sellers like RetailNet, TechRetail, SuperComNet, OmniTechRetail etc. were now seen to be selling things up on Flipkart instead of the only visible name- WS Retail till date and all these new biggies now contributed around $60 \%$ of total sales on this platform (www.ETTech.com) though around 2016 Flipkart already had 80,000 sellers with a customer base of around 75 million (Economic Times, 2016). But, Flipkart now wanted to focus more on some 100 vendors that in total contributed $2 / 3^{\text {rd }}$ of the sales in order to provide quality services of marketplace along with personalized experience to the customers. Flipkart also planned to enter into agreements of direct sales with many manufacturers. (e.g. During this time it signed a deal with Godrej Interio to list it as seller on Flipkart and sell things directly on it)

However, things aren't easy in business. The problems continued for this so-called Indian (born in Singapore) giant with context of posting continuous losses leading to pressure from investors. The following table shows the struggle of Flipkart with reference to revenues-

\begin{tabular}{|l|l|l|l|l|l|}
\hline \multicolumn{6}{|c|}{ Standalone Financials of Flipkart India Private Limited (Table-2) } \\
\hline Year & FY'14 & FY'15 & FY'16 & FY'17 & FY'18 \\
\hline Revenue (Rs. In Billion) & 28.4 & 95.3 & 131.7 & 155.6 & 216.5 \\
\hline Profit (Rs. In Billion) & $\mathbf{- 4 . 0}$ & $\mathbf{- 8 . 3}$ & $\mathbf{- 5 . 4}$ & $\mathbf{- 2 . 4}$ & $\mathbf{- 2 0 . 6}$ \\
\hline
\end{tabular}

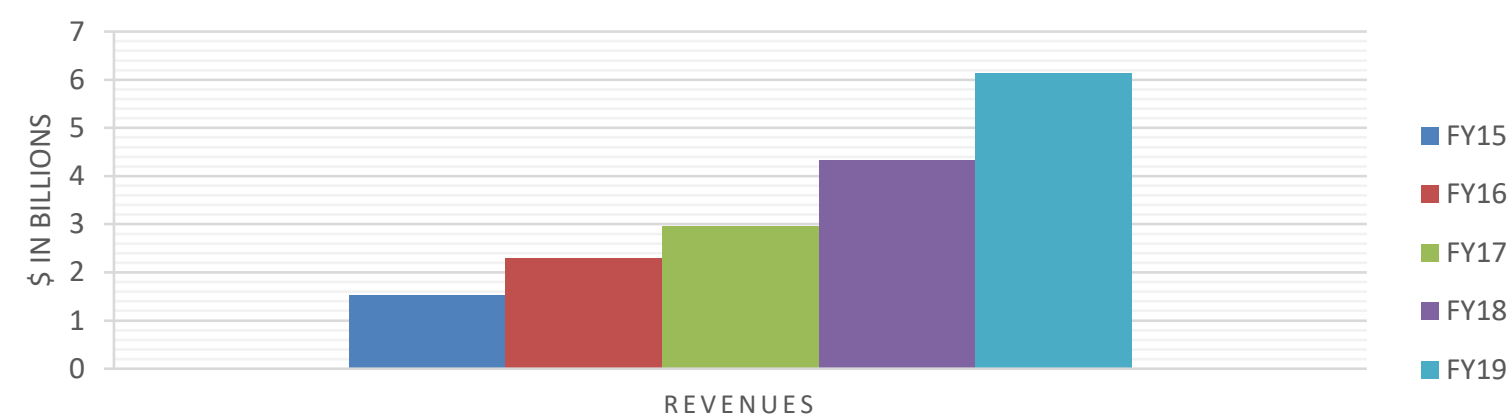

FLIPKART SINGAPORE FINANCIALS (CHART-1)

FLIPKART SINGAPORE (REVENUE GROWTH IN \%) (Chart- 2)

REVENUE GROWTH

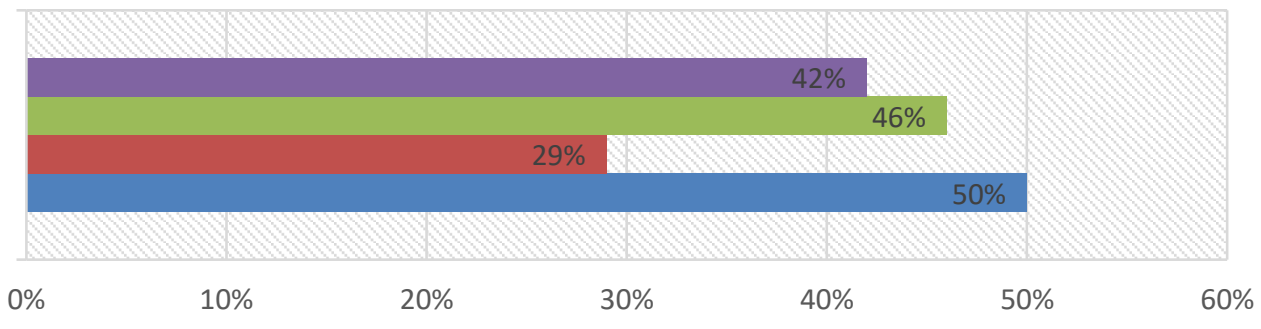

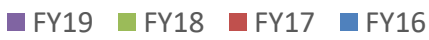

As the financials didn't support it's growth story, may be it was time for Bansals to call it a day and pass on the baton of Flipkart (after burning cash of around 2.32billion dollars) to some genuine investor. They found one in the form of Walmart. The American retail giant was planning to unleash it's potential in developing nations and India with promising growth potential promise, Walmart took it over from Flipkart founders for around 16 billion dollars with around $77 \%$ holding. The deal also included a condition to find new investors as well as to be bring in a fresh capital of around \$2billion. Walmart continued the strategy of Flipkart and continued with it's small bunch of dedicated sellers, till end 2018. But the twist in the tale was now about to come and the problems had not ended. 


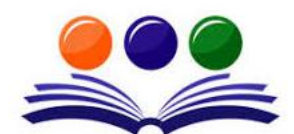

GRAND ACADEMIC PORTAL RESEARCH JOURNALS

\section{A GLOBAL JOURNAL OF SOCIAL SCIENCES}

( ISSN - 2581-5830 )

Impact Factor: SJIF - 4.998, IIFS - 4.375

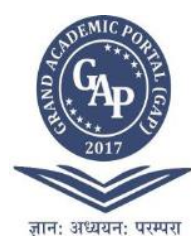

stored and managed by Amazon in their Fulfillment Centres giving rise to the question of ownership of inventories. However, in its defence of title to ownership of goods Amazon clarified that the fulfilment centres only facilitate storage by third party sellers and it does not own any of those products or involve in the pricing strategies of the vendors.

4.2. Amazon's Investment in Retail Venture: A Timeline (Table-3)

\begin{tabular}{|c|c|}
\hline Year & Review \\
\hline 2008 & $\begin{array}{l}\text { Amazon Asia Pacific Resources Pvt. Ltd was registered in Singapore with business in computer } \\
\text { programming services }\end{array}$ \\
\hline \multirow[t]{2}{*}{2009} & $\begin{array}{l}\text { Catamaran Management Services Pvt. Ltd registered in Karnataka India as an unlisted company } \\
\text { floated by Narayan Murthy and Arjun Narayan as founder members to invest into profitable joint } \\
\text { venture opportunities. }\end{array}$ \\
\hline & Amazon Eurasia Holdings VBA headquartered in Luxembourg \\
\hline 2010 & $\begin{array}{l}\text { Amazon Seller Services Pvt. Ltd. was registered in Karnataka India to provide telephone voice } \\
\text { and data communications service and it operates as www.amazon.in, the online portal. [It's } \\
100 \% \text { holding lies with Amazon Asia Pacific Resources Pvt. Ltd and Amazon Eurasia Holdings } \\
\text { VBA, and they both are subsidiaries of Amazon.com Inc.,U.S.A.] }\end{array}$ \\
\hline 2011 & $\begin{array}{l}\text { Cloudtail India Pvt. Ltd. was incorporated and was registered to be involved in business of Other } \\
\text { Wholesale.[i.e. wholesale in variety of goods without any specialization] }\end{array}$ \\
\hline \multirow[t]{2}{*}{2012} & $\begin{array}{l}\text { Prione Business Services Pvt. Ltd. was formed as a Joint venture between Catamaran, Amazon } \\
\text { Asia Pacific Resources Pvt. Ltd and Amazon Eurasia Holdings VBA with 51\%, } 48 \% \text { and } 1 \% \\
\text { holding respectively. }\end{array}$ \\
\hline & $\begin{array}{l}\text { Appario Retail Private Limited was incorporated as a Joint Venture between Ashok Patni Group } \\
\text { and Amazon (Formerly known as Aristotle Sales and Marketing Private Limited) and it is a } \\
\text { wholly known subsidiary of Frontizo Business Services Private Limited and deals in trading in } \\
\text { retail goods }\end{array}$ \\
\hline 2014 & $\begin{array}{l}\text { Prione Business Services Pvt. Ltd. acquired Cloudtail India Pvt. Ltd and thus Cloudtail became a } \\
\text { fully owned subsidiary of Prione } \\
\text { [Initial holding- Catamaran:51\% and Amazon:49\%] }\end{array}$ \\
\hline 2019 & $\begin{array}{l}\text { Amazon sold its } 25 \% \text { stake in Cloudtail to Prione [JV of Catamaran] to comply with the latest } \\
\text { requirements of restructuring as per FDI amendments. } \\
\text { [New holding- Catamaran:76\% and Amazon: } 24 \% \text { in compliance with Press note- } 2 \text { to be } \\
\left.\text { implemented by } 1^{\text {st }} \text { February } 2019\right]\end{array}$ \\
\hline
\end{tabular}

4.3. The story of Amazon before December 2018 FDI norms

4.3.1 Cloudtail India Private Limited-
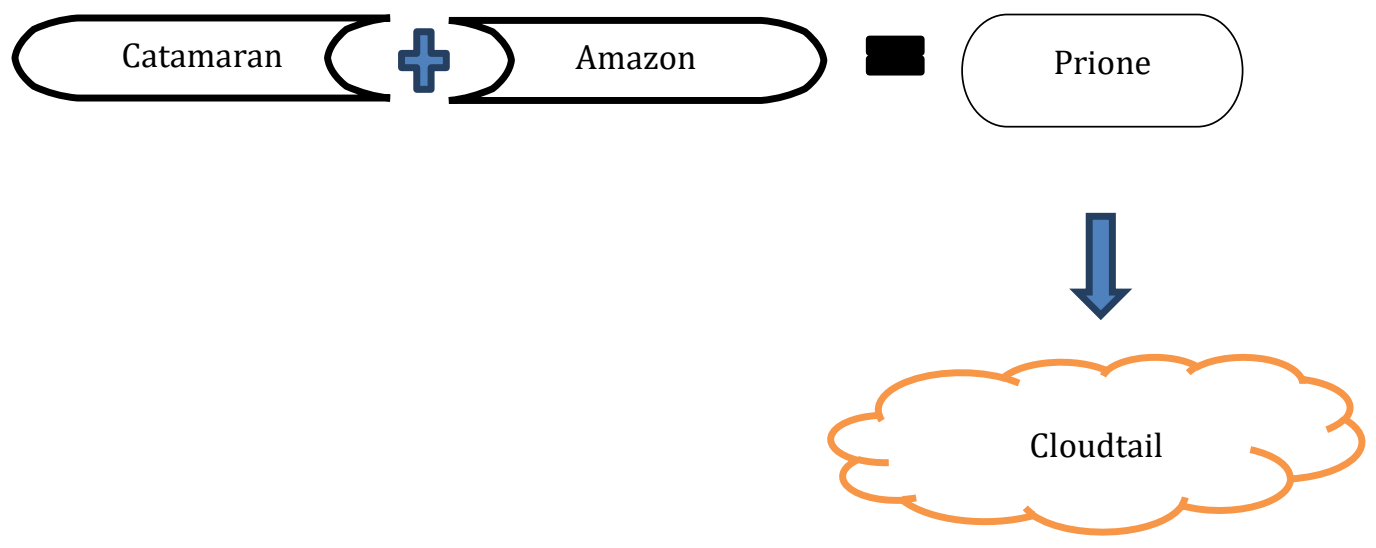

(Figure-1)

With the help of above diagram and table, it can be seen that Amazon has indirectly contributed to the equity holding of Cloudtail via Prione. If amazon had directly invested in majority in Cloudtail, it would have been an outright violation in the Indian FDI norms and so that is the main reason that Amazon joined hands with Catamaran (an Indian corporation) to form Prione paving an easy way for investement without being accused of FDI violations since it would count as downstream investment which was allowed. 


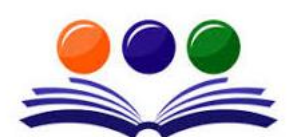

GRAND ACADEMIC PORTAL RESEARCH JOURNALS
A GLOBAL JOURNAL OF SOCIAL SCIENCES

( ISSN - 2581-5830 )

Impact Factor: SJIF - 4.998, IIFS - 4.375

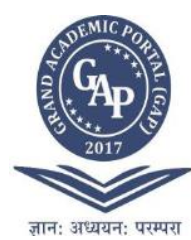

With majority shares in Prione being held by Catamaran Management Services, Prione was disguised as controlled by an Indian firm and thus its downstream investment would not have the FDI red flag. The fact, however, is that CMS was only a financial investor and the activities of Cloudtail were directly aligned with those of Amazon. Even assuming that CMS controlled Prione and Amazon's representatives on Prione's Board, being in minority, could not influence its decisions the fact remains that Catamaran joined hands with Amazon for the business it generated for Cloudtail which was finally going to sell it's products on Amazon. In fact, the Shareholders' Agreement between Amazon Asia Pacific and Amazon Eurasia and CMS gave certain rights to Amazon which also bound their Joint Venture Subsidiary like Cloudtail. Back then, Amazon had two of its nominees on the Board of Prione. It is important to note that the same nominees held senior positions in Amazon Sellers Services Private Limited as country head and finance director. Since Amazon is a marketplace model in India it is expected that it will have arm's length distance from the sellers. But its indirect ownership of Cloudtail in the past and presence of its vital recruits on the board of Prione back then elevated a grave question about such independence. However, the aim of Cloudtail has always been to support India's small and medium enterprises (SMEs) to levitate their businesses online from offline and tap the online market. The Memorandum of Association of Cloudtail, however, does not have any reference to the SME sector. Further back then, most of the products like mobile phones, electronic items, books sold by Cloudtail were hardly produced by small and medium enterprises of India. Also there is no evidence to show that Cloudtail charges lower commission from SME sellers. (Choudhury, R., 2015). However, this is a tale from the past because the FDI policy change in December 2018, changed a lot for Cloudtail and Amazon in India.

\subsubsection{Appario Retail Private Limited}

Appario another major seller on amazon was a setup between Amazon and Patni group and it's organizational and holding structure was quite similar to that of Cloudtail. Origanlly Ashok Patni's investment firm Zodiac Wealth Advisors held 51\%, Amazon Asia Pacific 48\% and Zaffre Investments LLC's 1\% stake to tackle C2C and B2C transactions for Frontizo.

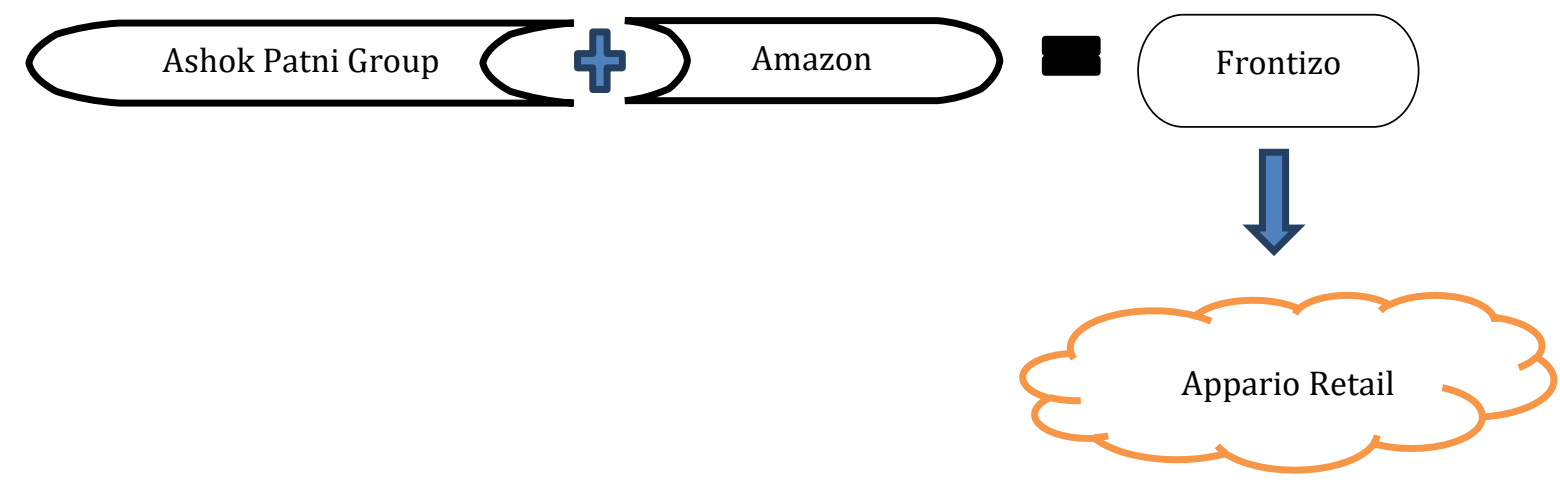

(Figure-2)

4.4. Survival after restructuring: Post 2018 FDI takedown

It is clear from this pictorial presentation that Amazon too wasn't in the good books of lacs of brick and mortar wholesalers and retailers of India, having built their chain of network since decades. These retailers were not only against these complex structure systems of such e-com biggies, but also with their marketing strategies and regular offers of deep discounts. Through regular complaints from their associations, they made sure that government came up with an amendment in the FDI policy, which didn't happen until December 2018.

Amazon had to finally suspend it's operation for almost a week in February 2019 following the new FDI rules. It had to go back to its drawing book in the board meetings and redesign their entre business network. And as they say, where there is law, there's a backdoor. Amazon made following changes-

Catamaran Ventures (owned by Narayana Murthy) increased it's stake in Prione Business Services to 76\% from earlier 51\% and brought down the stake of Amazon in that company to only $24 \%$ and hence now Cloudtail couldn't be defined as Amazon's group company and hence it can continue being a vendor on the platform of Amazon. Appario Retail, another giant on Amazon made such necessary changes in order to continue operating on Amazon marketplace platform since it was also a JV between Patni group and Amazon. (Economic Times, 2019) This changes definitely didn't happen completely in favor of Amazon and it had to reduce it's stake in such huge Indian retail market with immense potential. But it was definitely happy since it was not the lone sufferer of this law and other biggie Flipkart too made changes accordingly as already discussed above.

\section{CONCLUSION}

The major e-tail giants like Flipkart and Amazon are very much in line with the laws 'on paper', but whether such arrangements actually help small and medium scale enterprises at large is a matter of another vigorous and in-depth study. Though from the website of Flipkart, 'success stories' of small scale entrepreneurial setups 


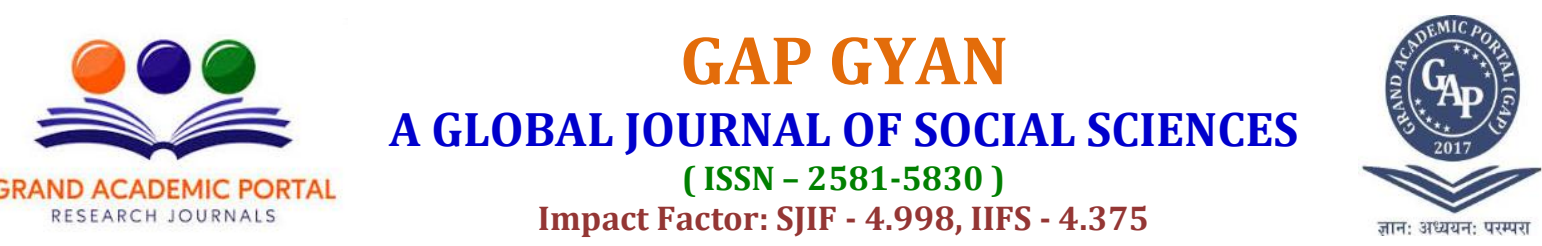

and some information available from Amazon's webpage they both definitely claim to have helped thousands of SME sector firms and setups. As end consumers, across the past decade we all have definitely benefitted in terms of deep-discounts on online purchases as these start-ups disrupted the centuries old wholesale-retail traditional mechanism in a vast country like India to a certain extent. But the path ahead is harder. The financials of both the companies with special reference to their businesses in India doesn't quite show a positive picture, which shows that discounts aren't diamonds that are forever! Also, now the FDI rules ban them from giving heavy discounts as well as not signing any exclusive sale deals with manufactures. This is some happy news for the Brick and Mortar shops, also because amidst the online boom, in October 2019, Flipkart had onboard nearly 27,000 kirana stores across 700 cities to its across India supply chain, helping it reach out to lakhs of new consumers during the festive season. Amazon also is not lagging behind, Cloudtail, a once upon a time group company too has around 30,000 small and medium sized entrepreneurs onboard. In the past there have been instances when some products like certain mobiles were sold only online via flash sales and not otherwise.

Flipkart Singapore bought goods worth Rs, 27376 Crores in financial year 2018 and worth Rs. 39514 crore in financial year 2019. An important question that arises here is why does a technology platform, a so called'marketplace' need to buy and sell goods on such a gigantic scale? The purchases made by Flipkart is almost $90 \%$ of the total purchases made by large Indian groups like D'Mart, Future Group (Future Retail \& Future Lifestyle), Aditya Birla Fashion \& Retail, Shoppers Stop and Trent together in Financial year 2019. If the FDI regulations for e-commerce are being honestly implemented, why does an earnest 'marketplace' like Flipkart need to buy goods at all? Also, what is the need to raise its buying by around $40 \%$ in a year if latest regulations are being followed in letter and spirit as demanded by the govenrnment? However, with reference to a court notice issued by Jodhpur bench of Rajasthan Highcourt regarding a petition filed by the Confederation of All India Traders (CAIT), alleging FDI policy violations, Flipkart officially said in a statement-

"We are fully compliant with FDI laws of the country. We are a marketplace player and work closely with lakhs of our sellers, artisans, and small and medium enterprises (SMEs) across the country. We help them connect with more than 16 crore customers. We are proud of our work to make these sellers and artisans successful and help in economic growth and job creation in India." (www.livemint.com)

While both Flipkart and Amazon claims to comply with the new FDI rules precisely, both seem to have well got away, by Amazon divesting a part of its holdings in large online seller entities- Cloudtail and Appario to comply with the changed rules and Flipkart by creating a layer of business-to-business entities to act as intermediaries between its wholesale entity and noticeable sellers on its platform. And recently, amidst the sad news of Corona wave hitting the world economies hard, the news of both Amazon and Flipkart going to increase their hiring were doing rounds following the immense increase in the online buying. The striking contrast here is that while the world is struck by probably worst recession in decades, Amazon.com INC's share listed at NASDAQ reached all-time new high of around $\$ 2400$ in the third week of April 2020. Hence, while as everything looks normal and settled for these two hulks even in India, in April 2020 Reliance group made a surprisingly mega announcement about their tie-up with Facebook for their soon to be launched marketplace involving the conventional offline retailers of India. Well, in the era of PUBG, may be as Indian TRPs are all eyeing towards reruns of Ramayana and Mahabharata on Doordarshan, Indian Retail Market is heading towards online battle of 'Kurukshetra' between these big players and who will take the last pie, is something we as consumers got to sit back, shop and enjoy.

\section{ANNEXURE 1: DEFINITIONS EXTRACTED FROM F.D.I. POLICY AS GIVEN BY D.I.P.P.}

1. E-commerce- E-commerce means buying and selling of goods and services including digital products over digital \& electronic network.

2. E-commerce entity- E-commerce entity means a company incorporated under the Companies Act 1956 or the Companies Act 2013 or a foreign company covered under section 2 (42) of the Companies Act, 2013 or an office, branch or agency in India as provided in section 2 (v) (iii) of FEMA 1999, owned or controlled by a person resident outside India and conducting the e-commerce business.

3. 'Government route' means that investment in the capital of resident entities by non-resident entities can be made only with the prior approval of Government (Competent Ministry/Department for grant of approval).

4. 'Group Company' means two or more enterprises which, directly or indirectly, are in a position to:

(i) exercise twenty-six percent or more of voting rights in other enterprise; or

(ii) appoint more than fifty percent of members of board of directors in the other enterprise.

5. 'Holding Company' would have the same meaning as defined in Companies Act, as applicable.

6. 'Indian Company' means a company incorporated in India under the Companies Act, as applicable.

7. Inventory based model of e-commerce- Inventory based model of e-commerce means an e-commerce activity where inventory of goods and services is owned by e-commerce entity and is sold to the consumers directly. 


\section{$\stackrel{00}{200}$ \\ GRAND ACADEMIC PORTAL RESEARCH JOURNALS

8. Marketplace based model of e-commerce- Marketplace based model of e-commerce means providing of an information technology platform by an e-commerce entity on a digital \& electronic network to act as a facilitator between buyer and seller.

\section{REFERENCES}

[1] 'Amazon steps up US lobbying in Indian FDI', Business Standard, April 28, 2014

[2] All the circulars, Press notes and FDI policies available at- https://dipp.gov.in/policies-rules-and-acts/pressnotes-fdi-circular

[3] Choudhury, R. N. 'India's FDI policy on E-commerce: some observations', ISID discussion Notes, available athttp://isid.org.in/pdf/DN1503.pdf

[4] http://articles.economictimes.indiatimes.com/2014-05-25/news/50083706_1_b2c-ecommerce-cent-fdi-dipp

[5] http://articles.economictimes.indiatimes.com/2015-03-19/news/60286677_1_ws-retail-binny-bansal-flip kart-spokesperson

[6] http://techcircle.vccircle.com/2014/11/06/flipkarts-in-house-vendor-ws-retail-sold-stuff-worth-rs-3135 cr-last-year/

[7] http://techcircle.vccircle.com/2014/11/06/peek-at-how-indias-top-three-e-commarketplaces-flipkart-amazon-snapdeal-fared/

[8] http://venturebeat.com/2018/12/26/india-bans-ecommerce-companies-from-delling-their-ownproducts/

[9] http://www.business-standard.com/article/companies/flipkart-changes-business-modellaunches-flipkart-marketplace/

[10] http://www.business-standard.com/article/companies/murthy-s-catamaran-partners-amazon-for-sme-pl atform-114062700830_1.html

[11] http://www.businessworld.in/en/storypage/-/bw/fdi-escapades/r544358.37489/page/

[12] http://www.dealcurry.com/20140724-Flipkart-Raises-Fresh-Round-Of-Funding.htm

[13] http://www.ecoti.in/bp69gZ

[14] http://www.forbesindia.com/article/10th-anniversary-special/ecommerce-what-the-past-10-yearsmean-for-the-future $/ 53513 / 1$

[15] http://www.livemint.com/Companies/5rcMyyEJgbQzZUnkJ9dRjJ/Amazon-stake-in-seller-may-come-und er-scrutiny.html

[16] http://www.livemint.com/Companies/VXr8oJzNJ4daOYSO5wNETN/Inside-Flipkarts-complex-structure/

[17] https://blog.aboutamazon.in/

[18] https://caravanmagazine.in/vantage/flipkart-dodged-laws

[19] https://economictimes.indiatimes.com/industry/services/retail/new-fdi-rules-had-little-impact-onamazon/articleshow/69066900.cms?from=mdr

[20] https://economictimes.indiatimes.com/industry/services/retail/new-fdi-rules-had-little-impact-onamazon/articleshow/69066900.cms?from=mdr

[21] https://entrackr.com/2018/06/flipkart-ws-retail-revenue-falls/

[22] https://entrackr.com/2018/08/flipkart-parted-2-bn-worth-ws-retail/

[23] https://entrackr.com/2018/08/w-s-retail-stop-seller-flipkart/

[24] https://entrackr.com/2019/11/flipkarts-financials-reveal-full-blown-retailer-not-marketplace/

[25] https://entrackr.com/2019/12/flipkart-wholesale-arm-receive-rs-2839-cr/

[26] https://inc42.com/buzz/major-online-sellers-to-limit-their-purchases-from-flipkart-wholesale/

[27] https://indianonlineseller.com/2016/05/cait-alleges-flipkart-violated-ecommerce-fdi-norms /

[28] https://m.economictimes.com/industry/services/retail/e-commerce-giant-flipkart-to-scale-downcontribution-of-ws-retail/articleshow/51885750.cms

[29] https://m.economictimes.com/industry/services/retail/flipkart-spencers-retail-confirms-partnershipflipkart-exploring-more-alliances/articleshow/75070820.cms

[30] https://m.economictimes.com/industry/services/retail/key-amazon-seller-cloudtail-returns-in-a-newavatar/articleshow/67877172.cms

[31] https://m.economictimes.com/industry/services/retail/key-amazon-seller-cloudtail-returns-in-a-newavatar/amp_articleshow/67877172.cms

[32] https://m.economictimes.com/industry/services/retail/small-online-sellers-ally-with-bigvendors/articleshow/63651598.cms 


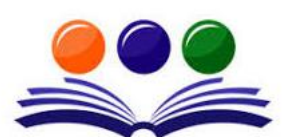

GRAND ACADEMIC PORTAL RESEARCH JOURNALS

\section{A GLOBAL JOURNAL OF SOCIAL SCIENCES}

( ISSN - 2581-5830 )

Impact Factor: SJIF - 4.998, IIFS - 4.375

[33] https://mybs.in/2VqqDUa

[34] https://stories.flipkart.com/tag/ecommerce-sellers/

[35] https://tech.economictimes.indiatimes.com/news/internet/new-e-commerce-norms-will-hit-amazonflipkarts-affiliated-sellers/67265618

[36] https://techstory.in/everything-you-wanted-to-know-about-indias-very-own-e-commerce-giant-flipkart/

[37] https://www.livemint.com/Companies/JYqTeqz4pjkpV2n5CcOMtO/The-20-billion-FlipkartWalmart-dealKey-facts.html

[38] https://www.livemint.com/companies/news/amazon-removes-numerous-products-from-indian-site-asnew-e-commerce-rules-bite-1548989634698.html

[39] https://www.livemint.com/industry/retail/after-court-notice-flipkart-says-it-s-fully-compliant-with-fdilaws-11570089591297.html

[40] https://www.livemint.com/Money/NWAHJVFkSBJsZJDuFCfvNL/Analysing-Flipkarts-financials-andWalmarts-real-cart-pric.html

[41] Kaila, P. (2015), "Top e-Retailers of India: business model and components", International Journal of Electronic Marketing and Retailing, Vol. 6 No. 4, pp. 277-298.

[42] KPMG-IAMAI, E-Commerce Rhetoric, Reality and Opportunity, 2013, (Executive Summary), available athttps://www.kpmg.com/IN/en/IssuesAndInsights/ArticlesPublications/Documents/KPMG-IAMAI-ES.pdf

[43] www.canva.com (for creating infographics)

[44] www.catamaran.in

[45] www.frontizo.in

[46] www.inc42.com/buzz/major-online-sellers-to-limit-their-purchases-from-flipkart-wholesale/

[47] www.prione.in

[48] www.zaubacorp.com 